\title{
Estimation of Water Footprint Components of Iran's Wheat Production: Comparison of Global and National Scale Estimates
}

\author{
Behnam Ababaei • Hadi Ramezani Etedali
}

Received: 26 January 2014 / Accepted: 24 March 2014 / Published online: 29 April 2014

(C) Springer International Publishing Switzerland 2014

\begin{abstract}
The water footprint (WF) of national wheat production has been previously estimated for the whole world in global-scale studies. These studies used assumptions which must be assessed and evaluated by estimates from national or regional studies. Here, previous estimates of different components (green, blue, gray and white) of WF of national wheat production in Iran were compared to the national-scale estimates. A new component (white WF) was proposed to account for the irrigation losses. Different components of the wheat WF were estimated for 236 plains over fifteen major wheat producing provinces. Then, the average values of each province were estimated. Finally, the weighted average values of each WF component were estimated by using the shares of irrigated and rainfed productions as weighting factors. The average total WF for irrigated areas and between all selected provinces is about $3,188 \mathrm{~m}^{3} /$ ton with comparable shares of blue and green water, while the average total WF for rainfed areas is about $3,071 \mathrm{~m}^{3} /$ ton with the share of the green WF nine times that of the gray WF. The results show that the total national WF of wheat production for the period 2006-2012 is about 42,143 million cubic meters (MCM) per year (41\% green, $18 \%$ blue, $16 \%$ gray and $25 \%$ white) with the share of the green WF about 2.3 times the blue WF. Comparison of the obtained estimates with the results of the previous studies at a global scale revealed that estimating the WFs of crops at a global scale, ignores the variations of climatic conditions, water resources availability and crop yields at the national and regional levels and some of the assumptions made in global-scale studies must be reassessed.
\end{abstract}

Keywords Virtual water $\cdot$ Water footprint $\cdot$ Wheat $\cdot$ Provincial scale $\cdot$ National scale

\section{Introduction}

Freshwater resources show enormous time and spatial variability from the viewpoints of availability and quality. Growing populations combined with socioeconomic developments

B. Ababaei $(\bowtie)$

Young Researchers and Elites Club, Science and Research Branch, Islamic Azad University, Tehran, Iran e-mail: Behnam.Ab@gmail.com

H. R. Etedali

Department of Water Engineering, Imam Khomeini International University, Qazvin, Iran 
put pressure on scarce water resources. Water consumption and pollution have exceeded the critical level in many parts of the globe (Mekonnen and Hoekstra 2010). Groundwater depletion, dying rivers and high pollution levels are all signs of growing water scarcity (Gleick 1993; Postel 2000; WWAP 2009). If humankind is to meet the challenges over the coming 50 years, the water use in agriculture has to be substantially reduced (Molden 2007).

In recent years, a new framework has been provided through the introduction of the "water footprint" (WF) concept by Hoekstra (2003), in analogy to the ecological footprint concept (Wackernagel and Rees 1996; Wackernagel et al. 1997; Wackernagel and Jonathan 2001). The concept was elaborated by Hoekstra and Chapagain (2008) and enables one to analyze the connection between human consumption and the allocation of the freshwater resources.

The WF of a product is defined as the total volume of freshwater that is used to produce the product (Hoekstra et al. 2011). The blue WF refers to the consumed (evaporated) volume of surface and/or groundwater in the production process of a good, and the green WF refers to the rainwater consumed. Hoekstra et al. (2009) define the gray WF of a product as the volume of freshwater that is required to assimilate the load of pollutants based on existing ambient water quality standards.

The virtual water content of a product is the freshwater 'embodied' in the product in virtual sense (Hoekstra et al. 2011). It refers to the volume of water consumed or polluted for producing the product, measured over its full production chain. Virtual water transfer, is a mechanism to save domestic water resources and achieve national water security (Allan 2003; Hoekstra 2003; De Fraiture et al. 2004; Liu et al. 2007; Oki and Kanae 2004; Chapagain et al. 2006; Yang et al. 2006; Hoekstra and Chapagain 2008). For example, international trade of agricultural commodities by importing water-intensive products and exporting water-extensive commodities results in saving scarce domestic water resources (Mekonnen and Hoekstra 2010). On the other hand, exporting water-intensive commodities brings considerable profits for water-abundant countries.

In this paper, the focus is on the WF components of wheat production, as one of the most widely cultivated cereal grains globally. Hoekstra and Hung $(2002 ; 2005)$ assessed the wheat production water use at a global scale in the period 1995-1999, and looked at total evapotranspiration (ET). Hoekstra and Chapagain $(2007,2008)$ made a similar assessment for the period 1997-2001. Liu et al. (2007) made a grid-based global assessment of water consumption in wheat production for the period 1998-2002. None of these three studies distinguished between green and blue water components. Liu et al. (2009) and Liu and Yang (2010) made a similar analysis with the green-blue water distinction. The global water consumption for wheat production with the green-blue water distinction was estimated by Siebert and Doll (2008; 2010) using a grid-based approach for the same period as Liu et al. (2007; 2009). GerbensLeenes et al. (2009) estimated the green and blue WF for wheat in the 25 largest producing countries. Aldaya et al. (2010) have estimated the green and blue water components for wheat in four major producing countries, and also estimated wheat-trade-related international virtual water flows. Aldaya and Hoekstra (2010) made an analysis of the WF of wheat in different regions of Italy, for the first time specifying the gray WF as well.

The water footprint of national wheat production was estimated previously for the whole world. Global-scale studies made assumptions which must be assessed and evaluated by the estimates from national or regional studies. Hence, this study aims to estimate the green, blue and gray WF of wheat in Iran, from a production perspective. These components were estimated at the regional scale and compared to the global-scale estimates. Furthermore, a new WF component (white) is proposed which accounts for the irrigation losses. 


\section{Materials and Methods}

In this study, the national green, blue, gray and white water footprint of wheat production were estimated following the calculation framework of Hoekstra and Chapagain (2008) and Hoekstra et al. (2009) with a few modifications. The estimations of crop ET and irrigation requirements under non-standard conditions have been done following the method and assumptions provided by Allen et al. (1998). The irrigation requirements and effective rainfall were estimated using the AGWAT model (IRIMO 2001). AGWAT is designed for the estimation of crop irrigation requirements under standard and non-standard conditions (Allen et al. 1998). The model was applied at a plain scale using the input data available in the model database. Irrigation was triggered whenever the root zone moisture depletion reached $50 \%$ of the total moisture available and filled the root zone moisture content back to the field capacity. Since the AGWAT calculates the gross irrigation requirements $\left(G I_{I r r}\right)$ for each 10-day period, the net irrigation requirements $\left(I R_{I r r}\right)$ were first calculated by considering irrigation efficiency $\left(I E_{I r r}\right)$ of each plain. Then, total effective precipitation $\left(P_{\text {eff }}\right)$ was calculated as the difference between total actual crop evapotranspiration $\left(E T_{c .}\right)$ and the total net irrigation requirements $\left(\mathrm{IR}_{\mathrm{Irr}}\right)$. After that, the green and blue crop water uses $(C W U)$ were estimated by the following equations:

$$
\begin{aligned}
& C W U_{\text {Blue }, I r r}=I R_{\text {Irr }}=10 \times I E_{\text {Irr }} \times G I_{\text {Irr }} \\
& C W U_{\text {Green }, I r r}=10 \times P_{\text {eff }}=10 \times\left(E T_{c}-I R_{\text {Irr }}\right) \\
& C W U_{\text {Blue }, R F}=0 \\
& C W U_{\text {Green }, R F}=10 \times P_{\text {eff }}
\end{aligned}
$$

where: $\operatorname{Ir} r$ and $R F$ refer to irrigated and rainfed conditions, respectively; and 10 is the conversion factor from $\mathrm{mm}$ to $\mathrm{m}^{3} /$ ha. The green $\left(W F_{\text {Green }}\right)$ and blue $\left(W F_{\text {Blue }}\right)$ water footprints $\left(\mathrm{m}^{3} /\right.$ ton $)$ are calculated by dividing the green and blue $C W U\left(\mathrm{~m}^{3} / \mathrm{ha}\right)$, respectively, by the actual crop yield (ton/ha). Since the yields are different under irrigated and rainfed conditions, the calculation of WF components were done with the respective actual yields under each condition. All WF components were estimated for all the plains (except for the provinces with more than 30 plains) in fifteen major wheat producing provinces (Table 1) which produce more than $86 \%$ of national wheat productions. For provinces with more than 30 plains, the plains with unique combinations of planting date and representative climatic stations were chosen. Irrigated and rainfed yields were obtained from Agricultural-Jihad Ministry (AJM) for the period 2006-2012 at a provincial scale.

Another component of the wheat production WF is the volume of water required to assimilate the fertilizers leached in runoff (gray WF). In this study, the gray water footprint $\left(W F_{\text {gray }}\right)$ related to nitrogen application was only estimated to make the results comparable to those from studies on a global scale. The $W F_{\text {gray }}$ of wheat $\left(\mathrm{m}^{3} / \mathrm{ton}\right)$ is calculated by the following equations:

$$
\begin{gathered}
W F_{\text {gray }, \text { Irr }}=\frac{\alpha_{I r r} \times N A R_{I r r}}{C_{\text {Max }}-C_{N a t}} \times \frac{1}{\text { Yield }_{\text {Irr }}} \\
W F_{\text {gray }, R F}=\frac{\alpha_{R F} \times N A R_{R F}}{C_{\text {Max }}-C_{N a t}} \times \frac{1}{\text { Yield }_{R F}}
\end{gathered}
$$

As the main purpose of this study was to compare the national and global estimates of WF components, the $\alpha$ values were assumed to be equal to the values applied by Chapagain et al. (2006) and Hoekstra et al. (2011)., i.e. on the average $10 \%$ and $5 \%$ for the applied nitrogen 


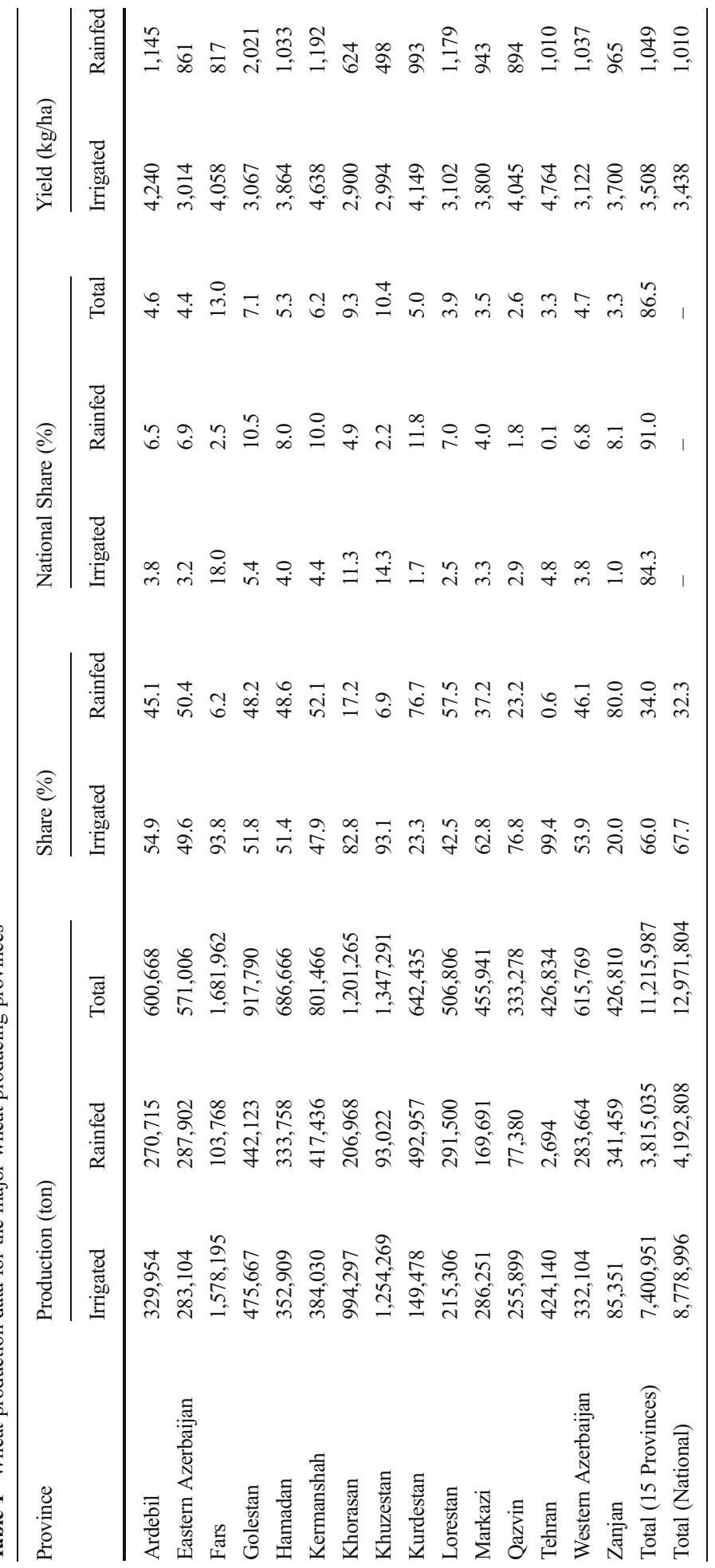


fertilizer under irrigated and rainfed conditions, respectively. Also, the maximum value $\left(C_{\text {Max }}\right)$ of nitrate in surface and ground water is recommended at $50 \mathrm{mg} / \mathrm{L}$ nitrate (NO3) or $10 \mathrm{mg} / \mathrm{L}$ as nitrate-nitrogen (NO3-N) by the World Health Organization and USEPA, respectively. In this study, the USEPA standard was considered (Chapagain et al. 2006). The natural nitrogen concentrations $\left(C_{N a t}\right)$ were assumed to be zero.

Moreover, the irrigation loss $\left(\mathrm{m}^{3} / \mathrm{ha}\right)$ was considered as a part of wheat WF and was named as "white water footprint":

$$
\begin{aligned}
W F_{\text {White,Irr }} & =\frac{10 \times\left(G I_{I r r}-I R_{I r r}\right)}{\text { Yield }_{\text {Irr }}} \\
W F_{\text {White }, R F} & =0
\end{aligned}
$$

The green, blue, gray and white WFs of wheat production for each province were estimated by taking the average WF $\left(\mathrm{m}^{3} /\right.$ ton) over the respective plains. Finally, the national WF components of wheat production were estimated by taking the average of each component over all the provinces weighted by the share of each province in the whole wheat production of the selected provinces, according to the data obtained from AJM.

After estimating the WF components $\left(\mathrm{m}^{3} / \mathrm{ton}\right)$ for each selected provinces, the total volumes of each component in each province and the national volumes of each component were calculated as the weighted average of the WFs under irrigated and rainfed conditions, using following equations:

$$
\begin{aligned}
& W F V_{i, x, y}=\operatorname{Prod}_{i, x, y} \times W F_{i, x, y} \quad i=1, \ldots, 15 \\
& A W F_{x, y}=\frac{\sum_{i} W F V_{i, x, y}}{\sum_{i} \operatorname{Prod} d_{i, x, y}} \\
& W A W F_{x}=\beta . A W F_{x, I r r}+(1-\beta) A W F_{x, R F} \\
& N W F_{x}=\text { TotProd.WAW } F_{x}
\end{aligned}
$$

where: $i$ : province index; $x$ : green, blue, gray or white; $y$ : Irr (irrigated) or $R F$ (rainfed); Prod: wheat production (Mton); WFV: the total volumes of each WF components (million cubic meters, MCM); $A W F$ : the average values of each WF component $\left(\mathrm{m}^{3} /\right.$ ton $) ; \beta$ : the share of irrigated wheat production in the whole country $(0.677)$; WAWF: the weighted average values of each WF component ( $\mathrm{m}^{3} /$ ton); TotProd: total wheat production (Mton); and NWF: the total national volumes of each WF components (MCM).

\section{Results}

Data on wheat production and nitrogen application rates $(N A R s)$ in fifteen major producing provinces is shown in Tables 1 and 2, respectively. In 2006-2012, more than $67 \%$ of the national wheat production was irrigated and $32.3 \%$ was rainfed, on the average, while $37.9 \%$ was irrigated and $62.1 \%$ was rainfed from more than 6,568 Kha of wheat cultivated lands.

Different components of wheat WF were estimated for 236 plains over fifteen selected provinces (Table 3, Figs. 1 and 2). For irrigated areas, the green WFs ranged from 499 to $1,023 \mathrm{~m}^{3} /$ ton, the blue WFs from 521 to $1,402 \mathrm{~m}^{3} /$ ton, the gray WFs from 337 to $822 \mathrm{~m}^{3} /$ ton, 
Table 2 Nitrogen application rates for selected provinces (2006-2012)

${ }^{1}$ Source: Agricultural-Jihad Ministry

\begin{tabular}{lll}
\hline Province & NAR $(\mathrm{kg} / \mathrm{ha})^{1}$ & \\
\cline { 2 - 3 } & Irrigated & Rainfed \\
\hline Ardebil & 267.9 & 23.0 \\
Eastern Azerbaijan & 111.3 & 43.7 \\
Fars & 333.7 & 65.3 \\
Golestan & 160.1 & 126.8 \\
Hamadan & 161.6 & 55.2 \\
Kermanshah & 261.4 & 83.6 \\
Khorasan & 192.5 & 17.0 \\
Khuzestan & 230.8 & 73.7 \\
Kurdestan & 156.4 & 54.4 \\
Lorestan & 154.7 & 81.6 \\
Markazi & 235.4 & 83.4 \\
Qazvin & 202.7 & 26.0 \\
Tehran & 228.3 & 25.0 \\
Western Azerbaijan & 105.1 & 31.1 \\
Zanjan & 193.4 & 94.2 \\
\hline & &
\end{tabular}

and the white WFs from 701 to $2,301 \mathrm{~m}^{3} /$ ton. The average total WF for irrigated areas among all selected provinces is about $3,188 \mathrm{~m}^{3} /$ ton, with almost equal shares of blue and green water (Table 4). For rainfed areas, the green WFs ranged from 1,282 to $4,166 \mathrm{~m}^{3} /$ ton and the gray WFs from 100 to $740 \mathrm{~m}^{3} /$ ton. The average total WF for rainfed areas is about $3,071 \mathrm{~m}^{3} /$ ton with the share of the green WF nine times the gray WF (Table 4).

Table 5 and Fig. 2 present the final estimation of national average values of different WF components. The weighted average values $(W A W F)$ are calculated by Equation (11). The (G) sign indicates the values estimated by Mekonnen and Hoekstra (2010) via a global assessment. As it can be seen, Mekonnen and Hoekstra (2010) estimated the green, blue and gray components of wheat production in Iran equal to 2,412, 988 and $290 \mathrm{~m}^{3} /$ ton, respectively. Here, the estimates of these components are revised to $1,328,571$ and $525 \mathrm{~m}^{3} /$ ton, respectively.

The total national WF (NWF) of wheat production for the period 2006-2012 is estimated at $42,143 \mathrm{MCM} /$ year (41 \% green, $18 \%$ blue, $16 \%$ gray and $25 \%$ white). About $86.3 \%$ of the total NWF related to wheat production is related to these fifteen provinces (Fig. 3). Fars $(13.2 \%)$, Khorasan (11.9\%) and Khuzestan (9.8\%) constitute $34.9 \%$ of the total $N W F$ related to the wheat production. In irrigated areas, these three provinces constitute $14.5 \%, 50.4 \%$, $43.0 \%$ and $52.1 \%$ of the total green, blue, gray and white WFs related to the wheat production, respectively. In rainfed areas, the largest green WFs can be found in Kurdistan $(9.2 \%)$, Kermanshah $(6.6 \%)$ and Zanjan $(5.7 \%)$. While the largest gray WFs are related to Tehran (2.4\%), Hamadan (2.1\%) and Kurdistan (2\%).

When consumptive water use (blue plus green WFs) is only considered, the WFs of wheat from rainfed and irrigated land are nearly equal. Similar conclusion was reached by Mekonnen and Hoekstra (2010). Although yields are considerably higher in irrigated areas, crop evapotranspiration $\left(E T_{c .}\right)$ is higher in these areas as well. In rainfed areas, the $E T_{c \text {. over }}$ the growing period is lower than the potential evapotranspiration $\left(E T_{p}\right)$, while under irrigated conditions there is more water available to meet crop water requirements, leading to an $E T_{c}$. near or equal to $E T_{p}$. 


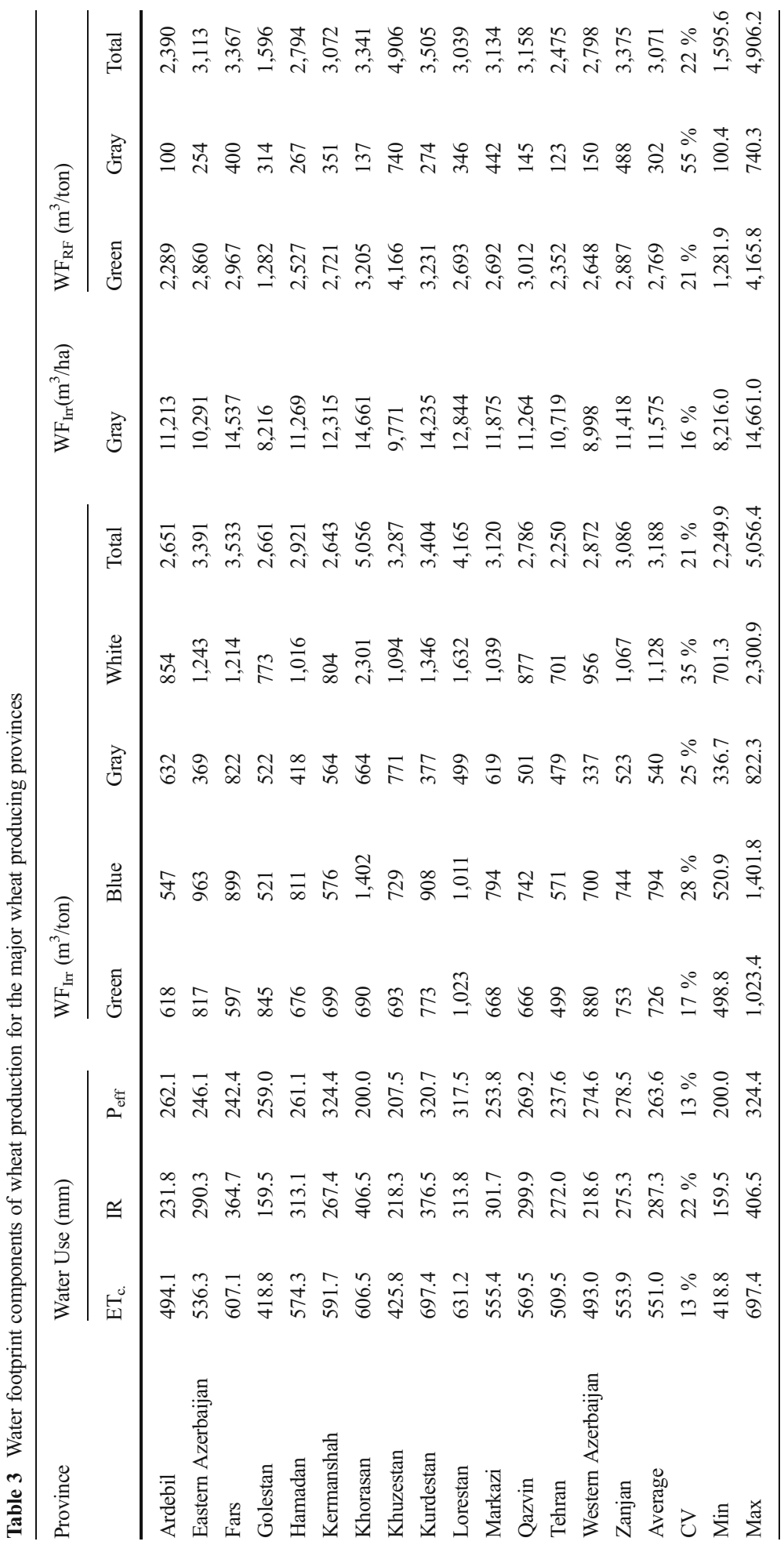




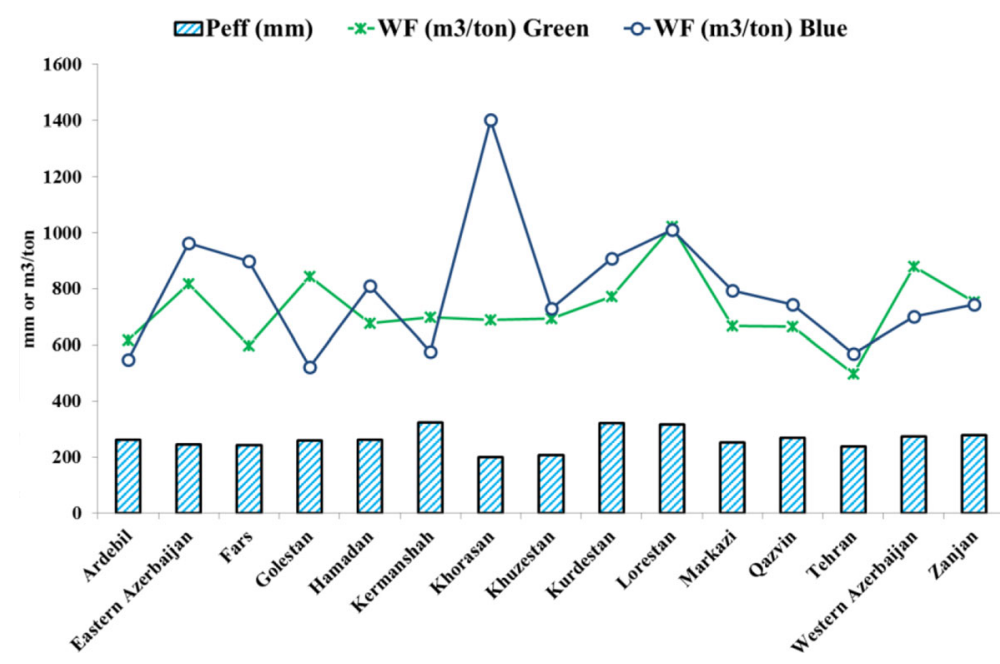

Fig. 1 Green and blue water footprints (WF) of wheat production and effective precipitation $\left(P_{\text {eff }}\right)$ for the major wheat producing provinces (2006-2012)

\section{Discussion}

The results of the current study with respect to the total national WF of wheat production can be compared to three previous global studies: the studies by Mekonnen and Hoekstra (2010), Liu et al. (2007) and Chapagain and Hoekstra (2004). The two latter studies did not take a grid-based approach and also did not make the green-blue distinction. The estimate of the total water footprint (blue + green) by Liu et al. (2007), $1,776 \mathrm{~m}^{3} /$ ton, is $6 \%$ lower and the estimate by Chapagain and Hoekstra (2004) (i.e. $2,925 \mathrm{~m}^{3} /$ ton) is $54 \%$ higher than our estimate. The GEPIC model tends to give lower estimates of ET compared to other models (Hoff et al. 2010), and this could be the reason of relatively lower values estimated by Liu et al. (2007). Chapagain and Hoekstra (2004) applied the model of Allen et al. (1998) which is the base of the AGWAT model.

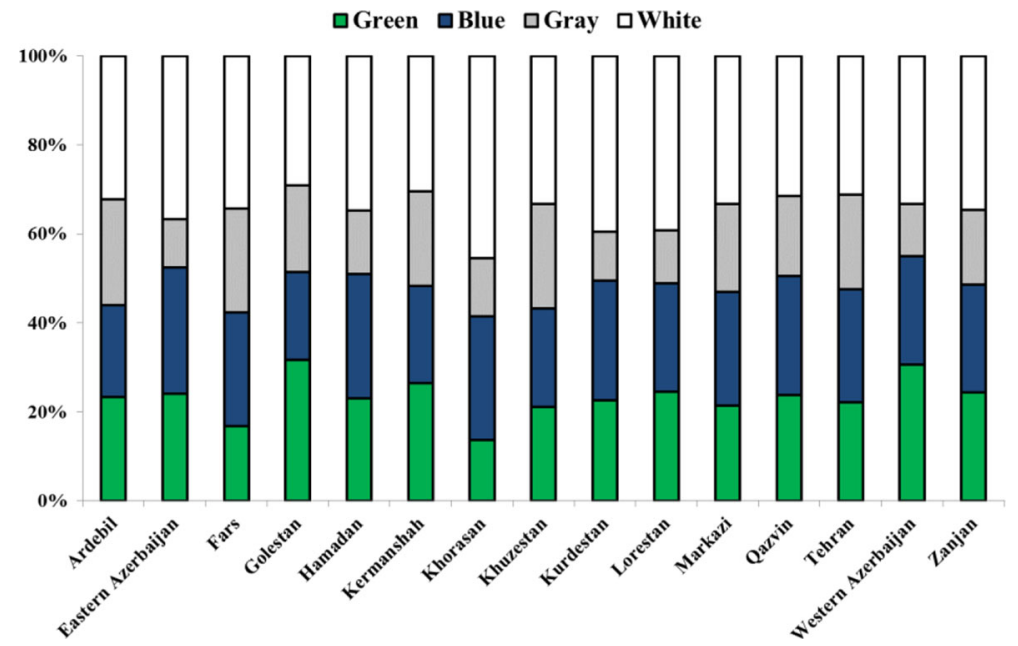

Fig. 2 The share of different WF components for the major wheat producing provinces 
Table 4 The share of different WF components for the major wheat producing provinces

\begin{tabular}{|c|c|c|c|c|c|c|}
\hline \multirow[t]{2}{*}{ Province } & \multicolumn{4}{|c|}{$\mathrm{WF}_{\mathrm{Irr}}(\%)$} & \multicolumn{2}{|c|}{$\mathrm{WF}_{\mathrm{RF}}(\%)$} \\
\hline & Green & Blue & Gray & White & Green & Gray \\
\hline Ardebil & 23 & 21 & 24 & 32 & 96 & 4 \\
\hline Eastern Azerbaijan & 24 & 28 & 11 & 37 & 92 & 8 \\
\hline Fars & 17 & 25 & 23 & 34 & 88 & 12 \\
\hline Golestan & 32 & 20 & 20 & 29 & 80 & 20 \\
\hline Hamadan & 23 & 28 & 14 & 35 & 90 & 10 \\
\hline Kermanshah & 26 & 22 & 21 & 30 & 89 & 11 \\
\hline Khorasan & 14 & 28 & 13 & 46 & 96 & 4 \\
\hline Khuzestan & 21 & 22 & 23 & 33 & 85 & 15 \\
\hline Kurdestan & 23 & 27 & 11 & 40 & 92 & 8 \\
\hline Lorestan & 25 & 24 & 12 & 39 & 89 & 11 \\
\hline Markazi & 21 & 25 & 20 & 33 & 86 & 14 \\
\hline Qazvin & 24 & 27 & 18 & 31 & 95 & 5 \\
\hline Tehran & 22 & 25 & 21 & 31 & 95 & 5 \\
\hline Western Azerbaijan & 31 & 24 & 12 & 33 & 95 & 5 \\
\hline Zanjan & 24 & 24 & 17 & 35 & 86 & 14 \\
\hline Average & 23 & 25 & 17 & 35 & 90 & 10 \\
\hline $\mathrm{CV}$ & 19 & 10 & 27 & 12 & 5 & 47 \\
\hline
\end{tabular}

The model of Allen et al. (1998) applies a runoff model and its results affect the soil water balance and soil water availability, and eventually, the calculation of green water footprint, while AGWAT does not calculate this kind of losses directly and uses the concept of effective precipitation. Besides, Liu et al. (2007) estimated water footprints $\left(\mathrm{m}^{3} / \mathrm{ton}\right)$ based on the simulated yields, whereas the actual yields were used in the present study. For estimating daily reference ET in this study, long-term monthly average reference ET values from the nearest climatic stations were used, while Chapagain and Hoekstra (2004) obtained the climatic data from the on-line database of the Tyndall Centre for Climate Change and Research (Mitchell and Jones 2005). As there are considerable spatial variations among the studied plains and provinces, the average data at a national scale could result in biased estimates of WF components.

Mekonnen and Hoekstra (2010) estimated the green, blue and gray WFs at 2,412, 988 and $290 \mathrm{~m}^{3} /$ ton, compared to our estimates of $1,328,571$ and $525 \mathrm{~m}^{3} /$ ton, respectively. Their estimated green and blue components are $82 \%$ and $73 \%$ higher and the gray component $45 \%$ lower than our estimates. They used a grid-based dynamic water balance model to calculate $C W U$ and yield over time, while in the current study, the actual average yields at a provincial scale were combined with a calibrated model (AGWAT) for estimating the irrigation requirements. Of course, this is not the main cause for these differences. It is believed that Mekonnen and Hoekstra (2010) estimated the weighted values of different WF (WAWF) components in a questionable way. Mekonnen and Hoekstra (2010) proposed an equation similar to equation (11) which used the irrigated and rainfed fraction of wheat area in each grid cell as the weighting factors, while the $W A W F s$ are related to the relative productions of these areas, not their shares of cultivated areas. Another reason for these differences is that Mekonnen and Hoekstra (2010) used wheat crop coefficients, planting dates and lengths of cropping season from the studies of Chapagain and Hoekstra (2004), Sacks et al. (2009) and Portmann et al. (2008). All these studies presumed the same values for the whole cultivated areas, while, our 
Table 5 The total volumes of each WF components for the major wheat producing provinces

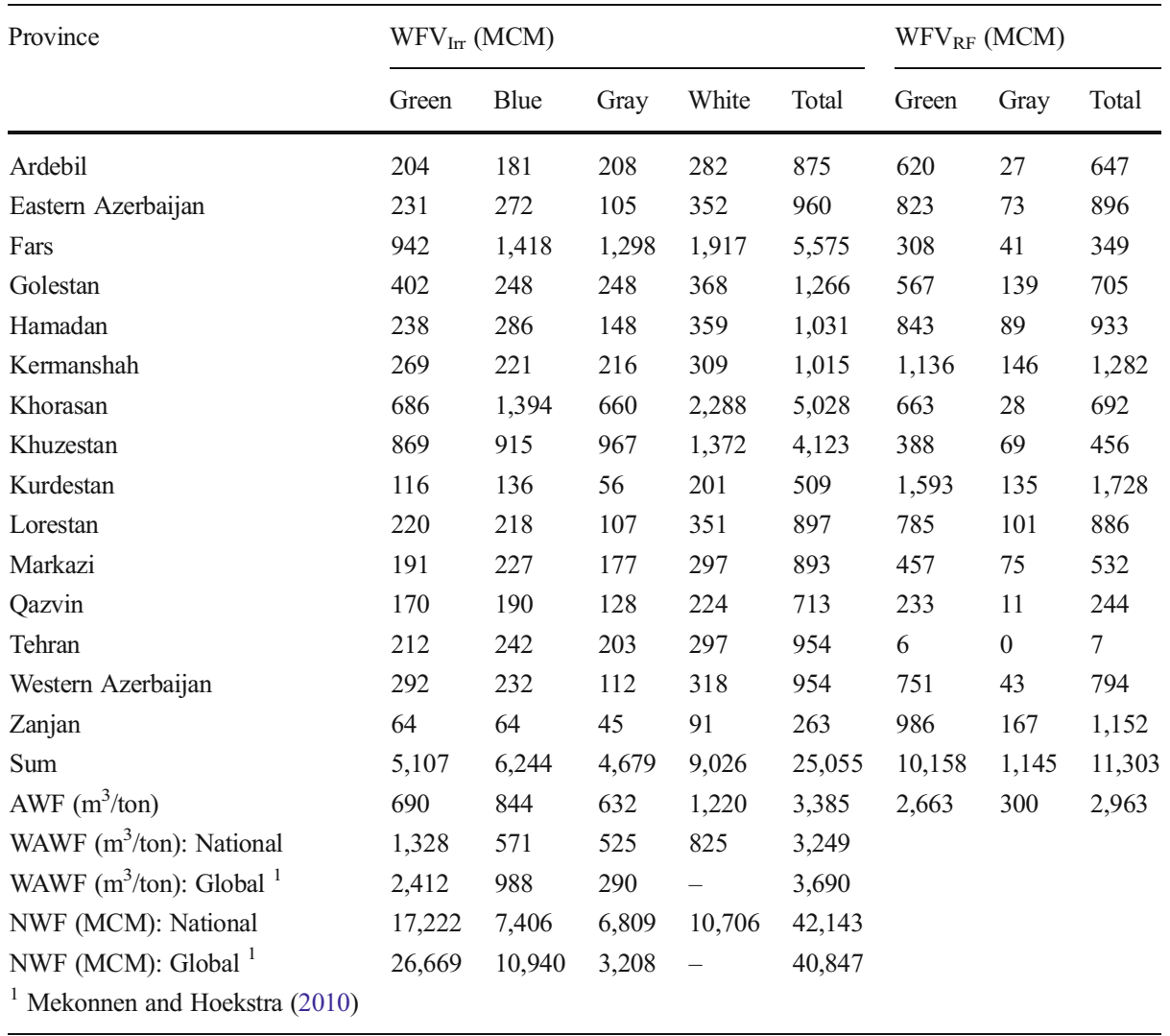

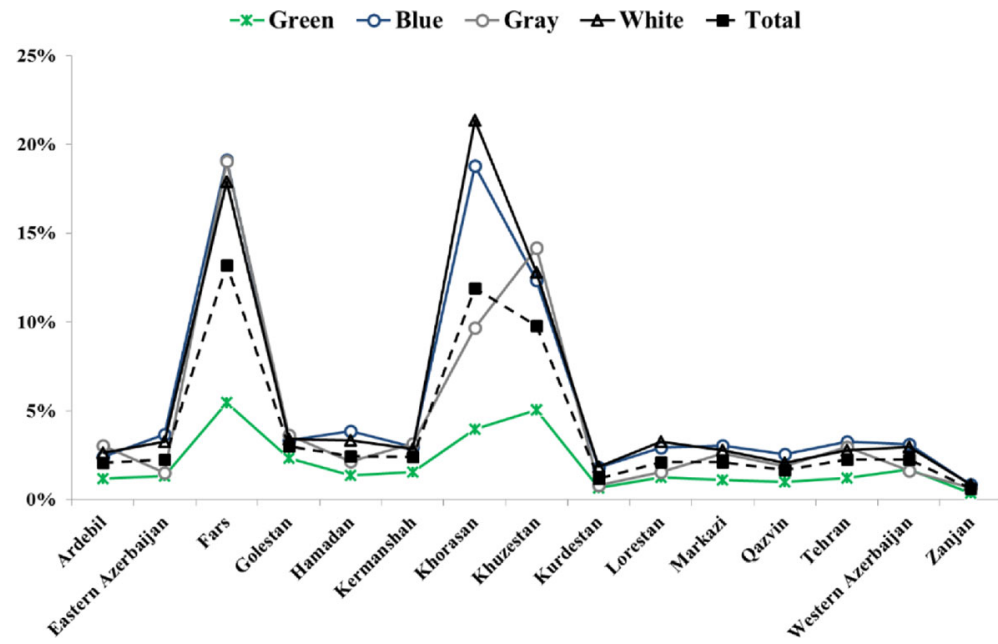

Fig. 3 The shares of the major wheat producing provinces from the national volumes of each WF components 
estimates seem more accurate than those of Mekonnen and Hoekstra (2010). The coefficients of variations $(\mathrm{CV})$ of $E T_{c}, I R$ and $P_{\text {eff }}$ between selected provinces are $13 \%, 22 \%$ and $13 \%$, respectively, which indicate considerable variations across the country and the need for using smaller assessment scales. With respect to the gray WF, Mekonnen and Hoekstra (2010) used a country-specific $N A R$ value. Instead, the average values at a provincial scale obtained from AJM were used here. It is rational to consider the provincial data more accurate than the estimates at a national or global scale.

A variety of assumptions about input data and modeling of yield have an influence on the green WF estimate (Mekonnen and Hoekstra 2010). The blue WF estimate depends also on actual irrigation data. In regional studies, it is generally less time-consuming to find better estimates for various parameters than in national studies, and it is easier to validate the models for local conditions and reduce uncertainties.

\section{Conclusions}

A simplified approach was applied to estimate the white WF component. The rough estimates about maximum acceptable concentration of nitrogen in the receiving water bodies can be improved by using more sophisticated models. Results revealed that estimating WFs of crops at a global scale and estimating international virtual water flows based on those estimates, ignores the variations of climatic conditions, water resources availability and crop yields at the national and regional levels. Therefore, estimation of WF at the plain scale is proposed. This approach is able to determine where the WF of wheat production is originally located.

It was found that the green WF related to the national wheat production in Iran is about 2.3 times the blue WF, confirming the importance of green water in wheat production. Green water generally has a lower opportunity cost compared to blue water (Mekonnen and Hoekstra 2010). Since wheat has relatively low economic water productivity as compared to many other crops (Molden 2007), the question "to which extent should water be allocated to wheat production in a water-scarce basin?" must be answered. The relatively low yields in rainfed areas show that there are still opportunities to lower the green WF. Increasing production from rainfed areas will reduce the need for production from irrigated lands in water-scarce areas, and thus reduce blue water use. The gray WF in wheat production can generally be lowered substantially by precision farming, so that less fertilizers leach to groundwater or end to surface water through runoff (Jenkinson 2001; Norse 2005).

It was revealed that some of the assumptions made in previous global scale studies can lead to biased estimates of total volumes of wheat production water footprint. The authors admit that the accuracy of these results is subject to the quality of the input data. All similar studies suffer from the same sorts of limitations and handle these limitations in different ways. In future studies, it would be essential to study the sensitivity of the results to the initial assumptions and assessing the existing uncertainties in the final results.

\section{References}

Aldaya MM, Hoekstra AY (2010) The Water Needed for Italians to eat Pasta and Pizza. Agr Syst 103:351-360 Aldaya MM, Allan JA, Hoekstra AY (2010) Strategic Importance of Green Water in International Crop Trade. Ecol Econ 69(4):887-894

Allan JA (2003) Virtual Water - the Water, Food, and Trade Nexus: Useful Concept or Misleading Metaphor? Water Inter 28(1):106-113 
Allen RG, Pereira LS, Raes D, Smith M (1998) Crop evapotranspiration: guidelines for computing crop water requirements. In: FAO Drainage and Irrigation Paper 56. Food and Agriculture Organization, Rome

Chapagain AK, Hoekstra AY (2004) Water footprints of nations. In: Value of Water Research. Report Series No 16, UNESCO-IHE, Delft, The Netherlands

Chapagain AK, Hoekstra AY, Savenije HHG (2006) Water Saving Through International Trade of Agricultural Products. Hydrol Earth Syst Sci 10:455-468. doi:10.5194/hess-10-455-2006

De Fraiture C, Cai X, Amarasinghe U, Rosegrant M, Molden D (2004) Does international cereal trade save water? The impact of virtual water trade on global water use. In: Comprehensive Assessment Research Report, Vol 4. International Water Management Institute, Colombo

Gerbens-Leenes W, Hoekstra AY, van der Meer TH (2009) The Water Footprint of Bioenergy. Proc Natl Acad Sci U S A 106(25):10219-10223

Gleick PH (ed) (1993) Water in crisis: A guide to the world's fresh water resources. Oxford University Press, Oxford

Hoekstra AY (ed) (2003) Virtual water trade: Proceedings of the International Expert Meeting on Virtual Water Trade, Delft, The Netherlands, 12-13 December 2002, Value of Water Research Report Series No12, UNESCO-IHE. Delft, The Netherlands

Hoekstra AY, Chapagain AK (2007) Water Footprints of Nations: Water use by People as a Function of Their Consumption Pattern. Water Resour Manag 21(1):35-48

Hoekstra AY, Chapagain AK (2008) Globalization of water: Sharing the planet's freshwater resources. Blackwell Publishing, Oxford

Hoekstra AY, Hung PQ (2002) Virtual water trade: A quantification of virtual water flows between nations in relation to international crop trade. In: Value of Water Research. Report Series No 11, UNESCO-IHE, Delft, The Netherlands

Hoekstra AY, Hung PQ (2005) Globalisation of Water Resources: International Virtual Water Flows in Relation to Crop Trade. Global Environ Chang 15(1):45-56

Hoekstra AY, Chapagain AK, Aldaya MM, Mekonnen MM (2009) Water footprint manual: State of the art 2009. In: Water Footprint Network. Enschede, The Netherlands

Hoekstra AY, Chapagain AK, Aldaya MM, Mekonnen MM (2011) The water footprint assessment manual: setting the global standard. Earthscan, London

Hoff H, Falkenmark M, Gerten D, Gordon L, Karlberg L, Rockstrom J (2010) Greening the Global Water system. J Hydrol 384:177-186

IRIMO (2001) Optimization of Agricultural Water Consumption. Islamic Republic of Iran Meteorological Organization.

Jenkinson DS (2001) The Impact of Humans on the Nitrogen Cycle, with Focus on Temperate Arable Agriculture. Plant Soil 228(1):3-15

Liu J, Yang H (2010) Spatially Explicit Assessment of Global Consumptive Water uses in Cropland: Green and Blue Water. J Hydrol 384:187-197

Liu J, Williams JR, Zehnder AJB, Yang H (2007) GEPIC - Modeling Wheat Yield and Crop Water Productivity with High Resolution on a Global Scale. Agr Syst 94:478-493

Liu J, Zehnder AJB, Yang H (2009) Global Consumptive Water use for Crop Production: The Importance of Green Water and Virtual Water. Water Resour Res 45:W05428. doi:10.1029/2007WR006051

Mekonnen MM, Hoekstra AY (2010) A Global and High-Resolution Assessment of the Green, Blue and Grey Water Footprint of Wheat. Hydrol Earth Syst Sci 14:1259-1276

Mitchell TD, Jones PD (2005) An Improved Method of Constructing a Database of Monthly Climate Observations and Associated High-Resolution Grids. Int J Climatol 25:693-712

Molden D (ed) (2007) Water for food, water for life: A comprehensive assessment of water management in agriculture. Earthscan, London

Norse D (2005) Non-point Pollution from Crop Production: Global, Regional and National Issues. Pedosphere 15(4):499-508

Oki T, Kanae S (2004) Virtual Water Trade and World Water Resources. Water SciTechnol 49(7):203-209

Portmann F, Siebert S, Bauer C, Doll P (2008) Global data set of monthly growing areas of 26 irrigated crops. In: Frankfurt Hydrology Paper 06. Institute of Physical Geography, University of Frankfurt, Frankfurt am Main

Postel SL (2000) Entering an era of Water Scarcity: The Challenges Ahead. Ecol Appl 10(4):941-948

Sacks WJ, Deryng D, Foley JA, Ramankutty N (2009) Crop Planting Dates: An Analysis of Global Patterns. Global Ecol Biogeogr 19(5):607-620

Siebert S, Doll P (2008) The global crop water model (GCWM): Documentation and first results for irrigated crops. In: Frankfurt Hydrology Paper 07. Institute of Physical Geography, University of Frankfurt, Frankfurt am Main

Siebert S, Doll P (2010) Quantifying Blue and Green Virtual Water Contents in Global Crop Production as Well as Potential Production Losses Without Irrigation. J Hydrol 384:198-207 
Wackernagel M, Jonathan L (2001) Measuring sustainable development: Ecological footprints. In: Centre for Sustainability Studies. Universidad Anahuac de Xalapa, Mexico

Wackernagel M, Rees W (1996) Our ecological footprint: Reducing human impact on the Earth. New Society Publishers, Gabriola Island, BC

Wackernagel M, Onisto L, Linares AC, Falfan ISL, Garcia JM, Guerrero IS, Guerrero MGS (1997) Ecological footprints of nations: How much nature do they use? How much nature do they have? Universidad Anahuac de Xalapa, Mexico, Centre for Sustainability Studies

WWAP (2009) The United Nations World Water Development Report 3: Water in a changing world. UNESCO Publishing, Paris/Earthscan, London, World Water Assessment Programme

Yang H, Wang L, Abbaspour KC, Zehnder AJB (2006) Virtual Water Trade: an Assessment of Water use Efficiency in the International Food Trade. Hydrol Earth Syst Sci 10:443-454. doi:10.5194/hess-10-4432006 